\title{
Effect of different levels of fermented rice bran for the growth of jelawat, Leptobarbus hoevenii
}

\author{
HENDRY YANTO $^{1, \bullet}$, JUNIANTO ${ }^{2}$, RITA ROSTIKA ${ }^{2}$, YULI ANDRIANI ${ }^{2}$, UJANG HIDAYAT TANUWIRIA ${ }^{3}$ \\ ${ }^{1}$ Program in Aquaculture, Faculty of Fisheries and Marine Sciences, Universitas Muhammadiyah Pontianak. Jl. Jend. Ahmad Yani No. 111, Pontianak \\ 78124, West Kalimantan, Indonesia. ”email: hendry_fpikump@yahoo.co.id \\ ${ }^{2}$ Department of Fisheries, Faculty of Fisheries and Marine Sciences, Universitas Padjajaran. Jl. Bandung-Sumedang Km 21, Jatinangor, Sumedang \\ 45363, West Java, Indonesia \\ ${ }^{3}$ Program in Animal Science, Faculty of Animal Husbandry,Universitas Padjadjaran. Jl. Bandung-Sumedang Km 21, Jatinangor, Sumedang 45363, West \\ Java, Indonesia
}

Manuscript received: 23 March 2018. Revision accepted: 28 April 2018.

\begin{abstract}
Yanto H Junianto Rostika R, Andriani Y, Tanuwiria UH. 2018. Effect of different levels of fermented rice bran for the growth of jelawat, Leptobarbus hoevenii. Nusantara Bioscience 10: 81-86. The prime objective of this study is to find the optimum level of fermented rice bran in diets beneficial to improve the digestive enzyme activity, growth and feed efficiency for jelawat (Leptobarbus hoevenii Bleeker). Different levels of fermented rice bran in the diets, i.e., A1 (10\%), A2 (20\%), A3 (30\%), A4 (40\%), and A5 (10\% non-fermented rice bran), as well as A6 (10\% commercial diet) was designed as a treatments during the study. The experimental diets with the same protein (isonitrogenous) and energy (isocaloric) were fed to jelawat fingerlings with an average of $32.57 \pm 0.15 \mathrm{~g}$ per fish. The results showed that amylase activities were significantly increased with the increased level of fermented rice bran levels in the diets and it was significantly different among the treatments $(\mathrm{P}<0,05)$. Proteins and lipids contents of the body and their retention rate, daily growth rates, and feed efficiencies were also significantly different among the treatments $(\mathrm{P}<0.05)$. It was concluded from the present investigation that up to $30 \%$ of fermented rice bran in the diet was best for jelawat with an optimum level of $25.66-26.78 \%$ for the growth performance and feed efficiency of jelawat.
\end{abstract}

Keywords: Fermentation, Leptobarbus hoevenii, rice bran

\section{INTRODUCTION}

Jelawat has good prospects in developing the aquaculture as same as freshwater fish. Being the most favorite fish in Southeast Asia such as Indonesia, Malaysia, and Brunei, it has high economic value and become one of Indonesia's export commodities (Warta Pasarikan 2010). It has been reproduced in mass production through induced breeding technology to support the aquaculture development. As an omnivorous fish with the tendency of being herbivore, it has the ability to efficiently utilize the carbohydrate energy from the plant.

Although it is agricultural waste, rice bran has been commonly used as an energy source for fish diet. It can be obtained easily and cheaply in large quantities. It also contains quite high nutrients, but with high fiber and lignin that provide digestible nutrients for jelawat, except for the ash in the rice bran (Law 1984). Therefore, the nutrient content and rice bran digestibility should be improved in order to be used as energy source for jelawat.

Improving the rice bran quality in the diet can be done through fermentation technology. It improves the content of nutrients and degrades the complex compounds to become simpler one that will increase the coefficients of digestibility and fish growth (Suprayudi et al. 2012; Mulyasari et al. 2013). Rice bran fermentation by using the Saccharomyces cerevisiae improves the protein content (Chinma et al. 2014). In addition, fermentation also decreases the fiber, lipid, ash and phytic acid in the fermentation materials (Flores-Miranda et al. 2014). Thus, it is required to test the use of fermented rice bran as the carbohydrates source in the diet on jelawat.

On the other hand, the fish ability in utilizing the carbohydrates is limited and varies from one another. Respectively, herbivorous and omnivores fish can utilize about $30-40 \%$ and $10-20 \%$ carbohydrate of the total feed formulation (Anderson and De Silva 2003). The fish ability to produce amylase enzyme and insulin sensitivity is low (Craig and Helfrich 2009). Thus, the increasing utilization of carbohydrate should be tested on the fish.

Increasing the utilization of carbohydrates can be done by determining the optimum carbohydrate level in the diet. Over carbohydrates in the diet may cause degeneration of liver cells and the over-accumulation of glycogen may also stimulate lipid inflation thereby causing liver disease in fish (Halver 1989); it decreased the efficiency of protein utilization and growth rate of the juvenile sunshine bass, Marone chrysops x Marone saxatilis (Hutchins et al. 1998) and juvenile European sea bass, Dicentrarchus labrax (Perez et al. 1997). However, when the carbohydrate level is low in the diet, high level of lipids and proteins should be provided, resulting in more expensive diet. Thus, increasing the utilization of different levels of fermented rice bran in the diets as a cheap energy source should be tested on jelawat. Due to mentioned reason, the objective of this study was designed as to determine the optimum 
level of fermented rice bran in diet, in order to increase the growth rate and feed efficiency of jelawat.

\section{MATERIALS AND METHODS}

\section{Experimental design}

Completely randomized design with different levels of fermented rice bran in the diets as the treatment was used during the study. The levels were: 10\% (A1), 20\% (A2), $30 \%$ (A3) and 40\% (A4) along with two controls viz. 10\% of unfermented rice bran (A5) and $10 \%$ of commercial diet (A6) were also used. Six treatments were applied with 3 replications for each treatment.

\section{Experimental diets}

The fermentation method was the same as the research done by Suprayudi et al. (2012). Rice bran was fermented by using the yeast Saccharomyces cerevisiae during experimentation. Based on the treatments, different levels of fermented rice bran were used during the study. The experimental diets were designed to have the same protein (isonitrogenous) of $30 \%$ and energy (isocaloric) of 2,700 $\mathrm{kcal} \mathrm{kg}^{-1}$. The experimental diet formulations and its proximate analysis results were presented in Table 1.

\section{Fish husbandry}

The experimental fish was jelawat having average weight of $32.57 \pm 0.15 \mathrm{~g}$. Eighteen units of $60 \times 40 \times 40 \mathrm{~cm}^{3}$ aquariums equipped with aeration system was used during the research filled with water up to $30 \mathrm{~cm}$ to reach $72 \mathrm{~L}$ of volume for 10 fish per aquarium. The top of each aquarium was covered with black screen to prevent the jelawat from jumping out. Jelawat was fed with experimented diets thrice in a day for 60 days ahead. The aquarium was cleaned every morning before feeding, and water was replaced as much as $70 \%$ of the total volume. During raising of jelawat, the water quality could normally support the growth and life of the fish with the composition of 5.75-6.50 ppm of dissolved oxygen, at $28-31^{\circ} \mathrm{C}$ temperature, $6.30-6.50$ of acidity degree $(\mathrm{pH})$ and $0.2-0.4$ ppm of total ammonia. This resulted in $100 \%$ survival rate of jelawat in all experimental units.

\section{Chemical analysis}

Proximate analysis was conducted to the ingredients of diets, experimental diets and the body of jelawat. In the proximate analysis of jelawat body, three samples of fishes for each experimental unit were taken. The test of water levels was done by heating the material sample for 24 hours in an oven at a temperature of $65^{\circ} \mathrm{C}$, and the test of crude protein levels was done by using Kjeldahl method, while the test of lipid content was by using the Folch method (Takeuchi 1988).

Table 1. Formulation and proximate analysis of experimental diets for jelawat according to the treatments $(\%)^{1)}$.

\begin{tabular}{|c|c|c|c|c|c|c|}
\hline \multirow{2}{*}{ Ingredients } & \multicolumn{6}{|c|}{ Formulation of experimental diets (\%) } \\
\hline & A1 & A2 & A3 & A4 & A5 & $\mathbf{A 6}^{2)}$ \\
\hline Fish meal & 30.00 & 30.00 & 30.00 & 30.00 & 30.00 & \\
\hline Soybean meal & 9.75 & 10.45 & 11.15 & 11.90 & 10.20 & \\
\hline Squid meal & 5.00 & 5.00 & 5.00 & 5.00 & 5.00 & \\
\hline Fermented rice bran & 10.00 & 20.00 & 30.00 & 40.00 & 0.00 & \\
\hline Unfermented rice bran & 0.00 & 0.00 & 0.00 & 0.00 & 10.00 & \\
\hline Pollard & 32.00 & 22.00 & 12.00 & 2.00 & 32.00 & \\
\hline Tapioca flour & 5.00 & 5.00 & 5.00 & 5.00 & 5.00 & \\
\hline Fish oil & 2.00 & 2.00 & 2.00 & 2.00 & 2.00 & \\
\hline Corn oil & 1.50 & 1.50 & 1.50 & 1.50 & 1.50 & \\
\hline Palm oil & 1.20 & 0.80 & 0.50 & 0.20 & 0.90 & \\
\hline Vitamin $\operatorname{mix}^{3)}$ & 1.00 & $\begin{array}{l}0.00 \\
1.00\end{array}$ & 1.00 & $\begin{array}{l}0.20 \\
1.00\end{array}$ & $\begin{array}{l}0.90 \\
1.00\end{array}$ & \\
\hline Mineral mix ${ }^{4)}$ & 1.00 & 1.00 & 1.00 & 1.00 & 1.00 & \\
\hline Cellulose & 1.55 & 1.25 & 0.85 & 0.40 & 1.40 & \\
\hline \multicolumn{7}{|l|}{ Content of nutrients: } \\
\hline Protein $(\%)$ & 30.06 & 30.08 & 30.14 & 30.09 & 30.19 & 30.96 \\
\hline Lipid (\%) & 10.54 & 10.48 & 10.38 & 10.29 & 10.97 & 8.05 \\
\hline Ash (\%) & 12.80 & 12.60 & 12.22 & 12.01 & 12.53 & 16.24 \\
\hline Crude fiber & 6.91 & 6.52 & 6.37 & 6.34 & 6.81 & 5.11 \\
\hline Nitrogen-free extract (\%) & 39.69 & 40.32 & 40.89 & 41.27 & 39.50 & 39.64 \\
\hline Digestibility energy $\left.(\mathrm{kcal})^{5}\right)$ & $2,680.64$ & $2,686.72$ & $2,690.24$ & $2,687.12$ & $2,717.20$ & $2,436.40$ \\
\hline Ratio Energy/Protein & 8.92 & 8.93 & 8.93 & 8.93 & 9.00 & 7.87 \\
\hline
\end{tabular}

Note: 1) water content of diets; A1 $=4.65 \% ; \mathrm{A} 2=4.42 \% ; \mathrm{A} 3=4.52 \% ; \mathrm{A} 4=4.94 \% ; \mathrm{A} 5=4.56 \% ; \mathrm{A} 6=5.28 \% ; 2)$ commercial diet; 3) every kg of vitamin mixture contains: vit. A 3,000,000 IU; vit. D3 1,000,000 IU; vit. K3 1,200 mg; vit. E 7,500 mg; vit. B1 $3.000 \mathrm{mg}$; vit. B2 4,500 mg; vit B6 3,000 mg; vit. B12 3,000 mg; vit. C 8,000 mg; Ca panthotenate 4,500 mg; Folic acid 1,500 mg; Biotin 1,000 mg; Inositol 12,500 mg; Nicotinamide $20.000 \mathrm{mg}$; Choline chloride $15.000 \mathrm{mg}$; L-Lysine 20,000 mg; DL-Methionine $5,000 \mathrm{mg} ; 4)$ every $100 \mathrm{~g}$ of mineral containing: $\mathrm{NaCl} 1.00 \mathrm{~g}$ macro minerals; $\mathrm{MgSO}_{4} 7 \mathrm{H}_{2} \mathrm{O} 15.00 \mathrm{~g} ; \mathrm{NaH}_{2} \mathrm{PO}_{4} \mathrm{H}_{2} \mathrm{O} 25.00 \mathrm{~g} ; \mathrm{KH}_{2} \mathrm{PO}_{4}$ 32.00 g; $\mathrm{Ca}\left(\mathrm{H}_{2} \mathrm{PO}_{4}\right) 2 \mathrm{H}_{2} \mathrm{O} 20.00 \mathrm{~g}$; Fe-citrate $2.50 \mathrm{~g}$; Trace element mix $1.00 \mathrm{~g}$; Ca-lactate $3.50 \mathrm{~g}$; micro minerals $\mathrm{ZnSO}_{4} 7 \mathrm{H}_{2} \mathrm{O} 35.30$ g; $\mathrm{MnSO}_{4} \mathrm{H}_{2} \mathrm{O} 16.20 \mathrm{~g} ; \mathrm{CuSO}_{4} 5 \mathrm{H}_{2} \mathrm{O} 3.10 \mathrm{~g} ; \mathrm{CoCl}_{2} 6 \mathrm{H}_{2} \mathrm{O} 0.10 \mathrm{~g} \mathrm{KIO} 30.30 \mathrm{~g}$ and $45.00 \mathrm{~g}$ cellulose; and 5) calculated in accordance with the energy values of protein $4 \mathrm{kcal} \mathrm{g}^{-1}$, lipid $8 \mathrm{kcal} \mathrm{g}^{-1}$ and carbohydrate $1.6 \mathrm{kcal} \mathrm{g}^{-1}$ (Halver 1989). 
Analysis of enzyme activity was done by taking the intestine of three fishes from each experimental unit. Fish intestines were mixed with distilled water up to ten times the weight and homogenized to obtained crude enzyme extract. The enzyme extract was stored in the refrigerator $\left(20^{\circ} \mathrm{C}\right)$ until the testing enzyme activity was done as protease by using the Hans-Helmar Walter method. Lipase and amylase were measured by the Borlongan method and Bernfeld method, respectively (Handayani 2006).

\section{Data analysis}

The hepatosomatic index (HSI) was calculated using the following formula used by Higgs et al. (2009). It was calculated under the following formula: $H S I=((W L) /$ $(W B)) \times 100 \%$. Where $H S I=$ hepatosomatic index $(\%), W L$ $=$ liver weight $(\mathrm{g})$ and $W B=$ body weight $(\mathrm{g})$.

Protein and lipid retention was calculated by using the formula of Takeuchi (1988): $R N=(N t-N o) / N p \times 100 \%$. Where $R N=$ retention of nutrients such as protein or lipid $(\%), N t=$ final protein or lipid contents of the fish body $(\%), N o=$ initial protein or lipid contents of the fish body $(\%)$, and $N p=$ protein or lipid diet content (\%).

The daily growth rate was calculated by using the formula proposed by Huisman (1976): $W t=W_{0}(1+$ $0.01 \alpha)^{\mathrm{t}}$. Where $W t=$ final fish biomass weight average $(\mathrm{g})$, $W_{o}=$ initial fish biomass weight average $(\mathrm{g}), t=$ duration of the experiment (day) and $\alpha=$ daily growth rate (\%).

Feed efficiency was calculated by using the formula proposed by Higgs et al. (2009) as follows: $e=F /$ ( Wt $W o) \times 100 \%$. Where $e=$ feed efficiency $(\%), F=$ the total amount of feed given during the experiment $(\mathrm{g}), W_{o}=$ initial biomass weight of fish $(\mathrm{g})$, and $W t=$ final biomass weight of fish $(\mathrm{g})$.

The variables such as digestive enzyme activity, HSI, protein and lipid content or retention of the body, daily growth rate, and feeding efficiency were analyzed statistically by using the analysis of variance and Duncan's multiple range test. Analysis regression was performed to determine the optimum levels of fermented rice bran in the diets. After that, statistical analysis was assisted by the PASW Statistics software version 18.

\section{RESULTS AND DISCUSSIONS}

\section{Enzyme activity}

Data revealed that the protease and lipase activities were not significantly different $(\mathrm{P}>0.05)$, but $\alpha$-amylase activity was significantly different $(\mathrm{P}<0.05)$ among the treatments. The activity of $\alpha$-amylase in treatments from A1 to A4 showed increase that was in line with the increasing levels of rice bran fermentation in the diets. The lowest activity of $\alpha$-amylase was in the treatment A5, and the highest was in the treatment A4 (Table 2).

\section{Body compositions}

Protein and lipid contents in the body were increased after the treatments as compared to earlier (Table 3). Jelawat body proteins were significantly different $(\mathrm{P}<0.05)$ among the treatments. The highest body protein was produced by commercial diet (treatment A6), but it was not significantly different $(\mathrm{P}>0.05)$ from the diet containing $30 \%$ of fermented rice bran (treatment $\mathrm{A} 3$ ). Based on regression analysis, it was formulated to $\mathrm{y}=0.0085 \mathrm{x}^{2}+$ $4.5 \mathrm{x}+44.85$ with $\mathrm{R}^{2}=0.9616$. The optimum fermented rice bran proportion in the diet to produce maximum body protein was $26.47 \%$.

Table 2. Protease, lipase and $\alpha$-amylase activities $(\mathrm{u} / \mathrm{mg}$ protein) on jelawat in final experiment.

\begin{tabular}{|c|c|c|c|}
\hline \multirow{2}{*}{ Treatments } & \multicolumn{3}{|c|}{ Enzyme activities (u/mg protein) } \\
\hline & Protease & Lipase & $\alpha$ Amylase \\
\hline A1 & $5.21 \pm 0.05^{\mathrm{a}}$ & $0.14 \pm 0.02^{\mathrm{a}}$ & $20.75 \pm 0.55^{\mathrm{ab}}$ \\
\hline A2 & $5.19 \pm 0.03^{\mathrm{a}}$ & $0.16 \pm 0.03^{a}$ & $21.57 \pm 0.86^{c}$ \\
\hline A3 & $5.18 \pm 0.05^{\mathrm{a}}$ & $0.14 \pm 0.02^{\mathrm{a}}$ & $22.93 \pm 0.08^{d}$ \\
\hline A4 & $5.17 \pm 0.05^{\mathrm{a}}$ & $0.14 \pm 0.01^{\mathrm{a}}$ & $23.64 \pm 0.09^{\mathrm{e}}$ \\
\hline A5 & $5.17 \pm 0.04^{\mathrm{a}}$ & $0.15 \pm 0.01^{\mathrm{a}}$ & $20.52 \pm 0.05^{a}$ \\
\hline A6 & $5.23 \pm 0.03^{\mathrm{a}}$ & $0.13 \pm 0.01^{\mathrm{a}}$ & $21.14 \pm 0.57^{b c}$ \\
\hline
\end{tabular}

Note: Means with a common superscript letter in the same column were not significantly different $(\mathrm{P}>0.05)$ by Duncan's test.

Table 3. Protein and lipid content or retention of the body for jelawat on before and after experimentation (in dry weight), and hepatosomatic index (HSI) (in wet weight) (\%).

\begin{tabular}{|c|c|c|c|c|c|}
\hline \multirow{2}{*}{ Treatments } & \multicolumn{5}{|c|}{ Body compositions } \\
\hline & Protein & Lipid & Protein retention & Lipid retention & Hepatosomatic index \\
\hline Initial & 48.71 & 20.46 & - & - & - \\
\hline A1 & $48.85 \pm 0.36^{\mathrm{ab}}$ & $21.72 \pm 0.74^{a b}$ & $23.49 \pm 0.63^{b}$ & $30.71 \pm 1.91^{\mathrm{b}}$ & $1.15 \pm 0.03^{b}$ \\
\hline A2 & $50.21 \pm 0.23^{c}$ & $23.14 \pm 0.62^{\mathrm{cd}}$ & $26.34 \pm 1.10^{\mathrm{c}}$ & $35.73 \pm 1.38^{c}$ & $1.17 \pm 0.02^{b}$ \\
\hline A3 & $50.94 \pm 0.45^{\mathrm{cd}}$ & $23.49 \pm 0.13^{\mathrm{d}}$ & $28.10 \pm 0,80^{\mathrm{d}}$ & $38.60 \pm 0.35^{\mathrm{d}}$ & $1.22 \pm 0.03^{\mathrm{c}}$ \\
\hline A4 & $49.17 \pm 0.75^{b}$ & $21.16 \pm 0.14^{\mathrm{ab}}$ & $23.66 \pm 0.12^{b}$ & $32.01 \pm 0.93^{b}$ & $1.25 \pm 0.02^{\mathrm{d}}$ \\
\hline A5 & $48.19 \pm 0.11^{\mathrm{a}}$ & $21.54 \pm 0.57^{\mathrm{a}}$ & $21.67 \pm 1.42^{\mathrm{a}}$ & $26.61 \pm 1.12^{\mathrm{a}}$ & $1.06 \pm 0.01^{\mathrm{a}}$ \\
\hline A6 & $51.63 \pm 0.61^{\mathrm{d}}$ & $22.58 \pm 0.75^{b c}$ & $27.64 \pm 0.14^{\mathrm{d}}$ & $46.00 \pm 0.67^{\mathrm{e}}$ & $1.18 \pm 0.01^{\mathrm{b}}$ \\
\hline
\end{tabular}


Table 4. Initial weight and final weight, daily growth rate, feed consumption and feed efficiency of jelawat after 60 days cultivation

\begin{tabular}{|c|c|c|c|c|c|}
\hline \multirow{2}{*}{ Treatments } & \multicolumn{5}{|c|}{ Variables of feed utilization } \\
\hline & $\mathrm{W}_{0}(\mathrm{~g})^{1)}$ & $W_{t}(g)^{2)}$ & DGR $(\%)^{3)}$ & FC $(g)^{4)}$ & FE $(\%)^{5)}$ \\
\hline A1 & $325.67 \pm 2.08$ & $1,173.33 \pm 3.51$ & $2.16 \pm 0.01^{b}$ & $1,523.00 \pm 2.65^{\mathrm{a}}$ & $55.66 \pm 0.55^{b}$ \\
\hline A2 & $326.00 \pm 1.00$ & $1.257 .67 \pm 15.04$ & $2.28 \pm 0.02^{c}$ & $1,512.67 \pm 2.08^{a}$ & $61.59 \pm 1.01^{\mathrm{c}}$ \\
\hline A3 & $325.33 \pm 2.08$ & $1.307 .67 \pm 15.37$ & $2.35 \pm 0.03^{\mathrm{d}}$ & $1,518.33 \pm 5.51^{\mathrm{a}}$ & $64.70 \pm 0.93^{\mathrm{d}}$ \\
\hline A4 & $325.00 \pm 1.00$ & $1.187 .33 \pm 17.21$ & $2.18 \pm 0.02^{b}$ & $1,517.33 \pm 13.87^{\mathrm{a}}$ & $56.84 \pm 1.17^{b}$ \\
\hline A5 & $326.67 \pm 2.08$ & $1.112 .33 \pm 22.81$ & $2.06 \pm 0.03^{\mathrm{a}}$ & $1,509.00 \pm 10.00^{\mathrm{a}}$ & $52.07 \pm 1.71^{\mathrm{a}}$ \\
\hline A6 & $325.33 \pm 1.53$ & $1.287 .33 \pm 7.77$ & $2.32 \pm 0.02^{\mathrm{d}}$ & $1,516.67 \pm 7.64^{\mathrm{a}}$ & $63.43 \pm 0.87^{\mathrm{cd}}$ \\
\hline
\end{tabular}

Note: 1) the weight of initial biomass, 2) the weight of final biomass, 3) daily growth rate, 4) feed consumption, 5) feed efficiency, and means with a common superscript letter in the same column were not significantly different $(\mathrm{P}>0.05)$ by Duncan's test

Body lipid of jelawat was significantly different (P $<0.05)$ among the treatments. The highest and the lowest jelawat body lipid was in the treatment A3 and the $10 \%$ of unfermented rice bran (treatment A5), respectively. The correlation between fermented rice bran level and body protein content formed regression equation of $\mathrm{y}=$ $0.0069 \mathrm{x}^{2}+0.3604 \mathrm{x}+18.773$ and $\mathrm{R}^{2}=0.9909$. The optimum fermented rice bran to produce the maximum body protein was $26.11 \%$ in the diet.

Protein retention was significantly different $(P<0.05)$ among the treatments. The highest protein retention was in the diet containing $30 \%$ of fermented rice bran (treatment A3), but it was not significantly different $(\mathrm{P}>0.05)$ from commercial diet. The lowest protein retention was in the diet containing $10 \%$ of unfermented rice bran. Based on the regression analysis, correlation between the fermented rice bran level and protein retention formed quadratic equation of $y=-1.8225 x^{2}+9.3395 x+15.717$ with $R^{2}=0.9121$. The optimum fermented rice bran level in the diet to produce the maximum protein retention was $25.66 \%$.

Lipid retention in jelawat was significantly different $(\mathrm{P}$ $<0.05)$ among the treatments. The highest and the lowest lipid retentions were in commercial diet and the diet containing $10 \%$ of unfermented rice bran, respectively. The maximum lipid retention generated by the diet containing optimum fermented rice bran was quantified as $26.19 \%$ by using the quadratic equation of $y=-0.029 x^{2}+1.5189 x+$ 18.058 and $\mathrm{R}^{2}=0.9309$.

Hepatosomatic index (HSI) tended to increase with the increase of fermented rice bran proportion in the diet. HSI was significantly different $(\mathrm{P}<0.05)$ among the treatments. HSI of the diets containing fermented rice bran were higher than unfermented rice bran. The highest and lowest levels of HSI were among the treatments A4 and A5, respectively.

\section{Utilization of diets}

Daily growth rate was significantly different $(\mathrm{P}<0.05)$ among the treatments. The lowest and highest daily growth rates were in the diet containing $10 \%$ of unfermented rice bran and $30 \%$ of fermented rice bran, respectively; but it was not significantly different from the commercial diet $(\mathrm{P}>0.05)$. The daily growth rates of jelawat fed with diets containing fermented rice bran were higher in compare to the diet with unfermented rice bran (Table 4). According to the regression analysis, the optimum level of fermented rice bran in the diet was $26.78 \%$ of the total diet formulation for jelawat, which was based on the quadratic equation of $\mathrm{y}=-0.0007 \mathrm{x}^{2}+0.0375 \mathrm{x}+1.8475$ and $\mathrm{R}^{2}=$ 0.9238 .

The feed efficiency was significantly different among the treatments $(\mathrm{P}<0.05)$. The lowest and highest feed efficiency levels were in the diet containing $10 \%$ of unfermented rice bran and $30 \%$ of fermented rice bran, respectively. All of the fermented rice bran in the diets producing feed efficiency that was higher than in the diet containing the unfermented rice bran. Then, the maximum feed efficiency produced by the optimum fermentation level of rice bran in the diet was $25.96 \%$ under the equation of $y=-0.0345 x^{2}+17,912 x+40.79$ and $R^{2}=0.9373$.

\section{Discussion}

Protease and lipase activities were not significantly different among treatments because protein and lipid in the diets were relatively the same as the enzyme substrate but the concentration of the substrate in the diet significantly affected the protease and lipase activity. This means that the activities of enzymes were positively correlated with the levels of their substrates (Lucas 2002; Krogdhal et al. 2005). Increasing levels of carbohydrates with the same protein content in the diets produced the same protease activity on Osphronemus gouramy after being maintained for 60 days (Handayani 2006). The larvae of sea bass ( $D$. labrax) was fed with the same lipid content. Thus the activity of lipase and phospholipase A2 (PL A2) were not significantly different because the modulation of their substrates, which were the triglyceride and phospholipids, was also relatively similar (Zambonino and Cahu 1999). Protease and lipase activities were in line with the levels of protein and lipid in the diet as a substrate.

The activity of $\alpha$-amylase was significantly different among the treatments $(\mathrm{P}<0.05)$, which was related to differences in the levels of starch or amylum in the diet as an $\alpha$-amylase substrate. Increasing the proportion of fermented rice bran means to increase the starch content in the diets. The starch substrate is hydrolyzed by $\alpha$-amylase (Krogdahl et al. 2005). The content of starch in the diet affects the activity of $\alpha$-amylase. For example, larvae of sea bass (D. labrax) which has $\alpha$-amylase activity is higher when it consumes the diet containing high starch as 
compared to low or no starch (Cahu et al. 2004). The activity of $\alpha$-amylase in $O$. gouramy also increases along with the increasing levels of carbohydrates in the diets (Handayani 2006). Increasing of $\alpha$-amylase activity is the result of modulation of starch in the diet. Then starch is utilized as a source of energy for the activity and metabolism whereas protein is utilized to synthesize body proteins beneficial for the growth.

High body protein in jelawat consuming control diet (A6) and high body protein and lipid in jelawat consuming $30 \%$ fermented rice bran (feed A3) were related to the energy balance of carbohydrate with protein and lipid in the diets. The carbohydrate in the diet was utilized as a source of metabolism energy by jelawat that the protein and lipid were saved as the growth energy. On the other hand, the carbohydrate was also used for the synthesis of non-essential amino acids and body lipid to support the growth (Bender and Mayes 2009). Therefore, as much as $30 \%$ of fermented rice bran in the diet was the best content to produce the protein and the highest body lipid in jelawat. However, based on regression analysis, the optimum fermented rice bran proportion in the diet to produce maximum body protein and body lipid in the diet was $26.47 \%$ and $26.11 \%$, respectively.

Jelawat consuming the diet containing as much as $30 \%$ of fermented rice bran was the best one among all for the production of protein and lipid contents in jelawat having high retention degree. However, based on the regression analysis, the optimally fermented rice bran level in the diet to produce the maximum protein retention was $25.66 \%$, and the maximum lipid retention generated by the diet containing optimally fermented rice bran was $26.19 \%$.

The increase of $\alpha$-amylase activity increased hepatosomatic index (HSI). The activity of $\alpha$-amylase which increased along with more fermented rice bran in the diet by using the treatment (A1-A4), increased the blood glucose of jelawat to fulfill the energy metabolism. Excess of glucose was stored in the form of glycogen and lipid in the fish liver and body. The ability of fish to utilize the carbohydrates depended on its ability to oxidize glucose from carbohydrates that were digested and stored as glycogen and lipid (Zhang et al. 2009). The more carbohydrates in the diet, the more glycogen and lipid stored in the liver, and in line with HSI score that was also getting higher. The same phenomenon was also shown in European seabass (Dientrarchus labrax) (Perez et al. 1997), the Asian seabass (Lates calcarifer) (Catacutan and Coloso 1997), sunshine bass (Marone chrysops $q$ x $M$. Saxalitis §) (Hutchins et al. 1998), Atlantic halibut (Hippoglossus hippoglossus) (Hatlen et al. 2005), transgenic coho salmon (Oncorhynchus kisutch) (Higgs et al. 2009), seabass (D. labrax) (Gatesoupe et al. 2014).

As the accumulation of $\alpha$-amylase activity, protein and lipid content of the body, protein and lipid retention in jelawat consuming the diets with fermented rice bran as the carbohydrate source produced the higher daily growth rates and feed efficiencies than those with unfermented rice bran. Adding the fermented carbohydrate sources in diets produced the high growth and fed efficiency in tawes, Puntius javonicus (Rostika 2010); common carp, Cyprinus carpio (Suhenda et al. 2010; Suprayudi et al. 2012); catfish hybrid, Heteroclarias spp. (Obe 2014). Fermented rice bran produced growth and feeding efficiently that was better than the unfermented rice bran in the diet.

Zhang et al. (2009) stated when carbohydrates are digested by fish, its ability to utilize carbohydrates as an energy source to support growth depends on metabolic enzymes and their assimilation. For example, coho salmon (O. kisutch) is capable to increase its activity of growth hormone, insulin growth hormone (IGF-1) and 3,5,3triiodothyronine to support its growth when there is optimum carbohydrate in the diet (Higgs et al. 2009). Therefore, there should be an optimum level of fermented rice bran in the diet in order to produce high daily growth rate and feed efficiency for jelawat.

The highest daily growth rate and feed efficiency were generated by the diet containing $30 \%$ of fermented rice bran. However according to regression analysis, to support the highest daily growth rate on jelawat, the optimum level of fermented rice bran in the diet for jelawat was $26.78 \%$ of the total diet formulation. Then the maximum feed efficiency to produce the optimum fermentation levels of rice bran in the diet was $25.96 \%$.

So, from the above findings it was concluded that the fermented rice bran in the diet produced amylase activity; protein and lipid contents of the body along with their retention; daily growth rate and feed efficiency that were better than unfermented rice bran. The level of optimum fermented rice bran to support the growth performance and maximum feed efficiency in jelawat ranged from $25.66 \%$ to $26.78 \%$ of the total diet formulation found during the study.

\section{REFERENCES}

Anderson T, De Silva S. 2006. Nutrition. In: Lucas SJ and Southgate CP (eds). Aquaculture, Farming Aquatic Animals and Plants. Blackwell Publishing, New York.

Bender DA, Mayes PA. 2009. Physiologically important carbohydrates. In: Murray RK, Granner DK, Mayes PA, Rodwell VW (eds.). Harper' Biochemistry. 27th ed., Pendit BU. [Indonesian translator]. Wulandari $\mathrm{N}$ et al. [Indonesian ed]. EGC, Jakarta. [Indonesian].

Cahu C, Ronnested I, Grangier, Zambonino LJ. 2004. Expression and activities of the pancreatic enzyme in developing sea bass larvae (Dicentrarchus labrax) in relation to intact and hydrolyzed dietary protein; involvement of cholecystokinin. Aquaculture 238: 295-308

Catacutan MR, Coloso RM. 1997. The growth of juvenile Asian seabass, Lates calcarifer, fed varying carbohydrate and lipid levels. Aquaculture 149: 137-144.

Chinma CF, Ilowefah M, Muhammad K. 2014. Optimation of rice bran fermentation condition enhanced by Baker's yeast for extraction of protein concentrate. Nigerian Food J 32 (1): 126-132.

Craig S, Helfrich LA. 2009. Understanding Fish Nutrition, Feeds, and Feeding. Virginia Cooperative Extension Publication 420-256: 1-4.

Flores-Miranda CM, Luna Gonzalez A, Cortes-Espinosa DV, CortesJacinto E, Fierro-Coronado JA, Alaves-Ruiz P, Gonzalez-Ocampo HA, Escamilla-Montes R. 2014. Bacterial fermentation of Lemna sp. as a potential subtitute of fish meal in shrimp diets. African $\mathrm{J}$ Microbiol Res 8 (14): 516-526.

Gatesoupe JF, Huelvan C, Bayon N, Severe A, Aasen IM, Degnes KF, Mazurais D, Panserat S, Zambino-Infate JL, Kaushik SJ. 2014. The effect of dietary carbohydrate source and forms on metabolic response and intestinal microboita in seabass juveniles, Dicentrarchus labrax. Aquaculture 422-423: 47-53. 
Halver EJ. 1989. Fish Nutrition. Academic Press Inc., Harcourt Brace Jovanich Publisher, San Diego.

Handayani S. 2006. The Study of the Efficient Utilization of Carbohydrate in Diets for the Growth of Carp (Osphronemus gouramy Lac.) in line with Changes in Digestive Enzymes and Insulin. [Dissertation]. School of Graduates, Bogor Agricultural University, Bogor. [Indonesian]

Hatlen B, Grisdale-Helland B, Helland SJ. 2005. Growth, feed utilization and body composition in two size groups of Atlantic halibut (Hippoglossus hippoglossus) fed diets differing in protein and carbohydrate content. Aquaculture 249: 401- 408

Higgs AD, Sutton JN, Kim H, Oakes JD, Smith J, Biagi C, Rowshandeli M, Devlin RH. 2009. Influence of dietary concentration of protein, lipid, and carbohydrate on growth, protein and energy utilization, and plasma titers of growth hormone and insulin and insulin-like growth factor-1 nontransgenic and growth hormone transgenic coho salmon, Oncorhynchus kisutch (Walbaum). Aquaculture 286: 127-137.

Huisman. 1976. Food convertion efficiencies, at maintenance and production levels for carp, Cyprinus carpio, and rainbow trout, Salmo gairdneri Richardson. Aquaculture 9 (1): 259-273.

Hutchins GC., Rawles SD, Gatlin III DM. 1998. Effects of dietary carbohydrate kind and level on growth, body composition and glycemic response of juvenile sunshine bass, Morone chrysops $\widehat{O} x M$. saxatilis ․ Aquaculture 161: 187-199.

Krogdahl A, Hemre GT, Mommesen TP. 2005. Carbohydrate in fish nutrition: digestion and absorption in the postlarval stage. Aquacult Nutr 11: 103-122.

Law TA. 1984. Nutritional study of jelawat, Leptobarbus hoevenii (Bleeker) fed on pelleted feed. Aquaculture 41: 227-233.

Lucas A. 2002. Bioenergetics of Aquatic Animals. Taylor \& Francis, New York.

Mulyasari, Kurniawati F, Setiawati M. 2013. Cassava digestibility through chemical and biological treatment as feed for tilapia. Indonesian Aquacult J 12 (2): 178-185. [Indonesian]
Obe BW. 2014. Growth performance and nutrient utilization of catfish hybrid (Heterobranchus bidorsalis x Clarias gariepinus) fed fermented sorghum (Sorghum bicolor) waste meal diets. Intl J Appl Sci Technol 4 (3): 130-136.

Perez L, Gonzalez H, Jover M, Fernandez-Carmona J. 1997. The growth of European sea bass fingerlings (Dicentrarchus labrax) fed extruded diets containing varying levels of protein, lipid and carbohydrate. Aquaculture 156: 183-193.

Rostika R. 2010. Improved corncob quality through fermentation of Trichoderma sp., Aspergillus sp., Rhizopus oligosporus and its consortium as carbohydrate source of fish feed and its effect on tawes performance (Puntius gonionitus). [Dissertation]. Graduate Program of Padjadjaran University, Sumedang. [Indonesian]

Suhenda N, Samsudin R, Melati I. 2010. Increasing the quality of vegetable materials (rice bran and pollard) through fermentation (Rhizopus oligosporus) and its use in the diets for common carp (Cyprinus carpio). In: Sudrajat A (ed). Proceedings of the Aquaculture Technology Innovation Forum. [Indonesian].

Suprayudi AM, Edriani G, Ekasari J. 2012. Evaluation of fermented product quality of various byproduct of local agroindustry: its influence on digestibility and performance of juvenile growth of common carp. Indonesian Aquacult J 11 (1): 1-10. [Indonesian]

Takeuchi T. 1988. Laboratory work-chemical evaluation of dietary nutrients. In: Watanabe T (ed) Fish Nutrition and Mariculture. Japan, JICA Textbook, The General Aquaculture Course. Departement of Aquatic Bioscience, Tokyo University of Fisheries, Tokyo.

Warta Pasarikan. 2010. Jelawat is belle from number province. Domestic Market Directorate, Directorate General of Processing and Marketing of Fishery. Marine and Fisheries Ministry, Jakarta. [Indonesian].

Zambonino JL, Cahu C. 1999. High dietary lipid levels enhance digestive tract maturation and improve Dicentrarchus labrax larval development. J Nutr 129: 1195-1200.

Zhang LL, Zhou QC, Cheng YQ. 2009. Effect of dietary carbohydrate level on growth performance of juvenile spotted Babylon (Babylonia areolata Link 1807). Aquaculture 295: 238-242. 